\title{
PENGARUH PEMBELAJARAN FISIKA DENGAN PENDEKATAN INDUKTIF MELALUI METODE EKSPERIMEN DAN DEMONSTRASI TERHADAP HASIL BELAJAR KOGNITIF SISWA KELAS X MASAFINATUNNAJANW REPOK OAK
}

\author{
Tuti Zikriana ${ }^{1}$, Ahmad Zohdi $^{2}$ dan Muhammad Kafrawi ${ }^{3}$ \\ ${ }^{1}$ Universitas Islam Negeri Mataram, Matara, 83116, Indonesia \\ Email: tutizikriana10@gmail.com \\ ${ }^{2,3}$ Program Studi Tadris Fisika, Fakultas Tarbiyah dan Keguruan, Universitas Islam Negeri Mataram, Mataram, 83116, \\ Indonesia
}

Email: ${ }^{2}$ ahmadzohdi@gmail.com; ${ }^{3}$ awi_fisika@uinmataram.ac.id

Diajukan: 11 January 2021; Diterima: 20 February 2021; Diterbitkan: 30 April 2021

\begin{abstract}
Abstrak: Penelitian ini bertujuan untuk untuk mengetahui ada tidaknya perbedaan pengaruh pembelajaran fisika dengan pendekatan induktif melalui metode eksperimen dan demonstrasi terhadap hasil belajar kognitif siswa kelas X MA Safinatunnaja NW Repok Oak.Penelitian ini menggunakan metode eksperimen dengan desain faktorial. Populasi dalam penelitian ini adalah seluruh siswa kelas X Semester II SM Safinatunnaja NW Repok Oak Tahun Ajaran 2018/2019. Teknik pengumpulan data yang digunakan adalah teknik observasi, teknik dokumentasi dan teknik tes. Implikasi dari hasil penelitian adalah bahwa pembelajaran Fisika dengan pendekatan induktif menggunakan metode eksperimen memberikan pengaruh yang lebih baik dengan mendapatkan nilai rata-rata terhadap hasil kognitif sebesar 90.21 dari 28 siswa, sedangkan pada penggunaan metode demonstrasi mendapatkan nilai rata-rata sebesar 80.87 dari 31 siswa. Selain itu kemampuan awal siswa kategori tinggi akan memberikan kemampuan kognitif yang lebih baik dibanding dengan kemampuan awal siswa kategori sedang dan rendah. Berdasarkan hasil analisis penelitian dapat disimpulkan bahwa ada pengaruh penggunaan pendekatan induktif melalui metode eksperimen terhadap hasil belajar kognitif siswa. Kemudian ada pengaruh penggunaan pendekatan induktif melalui metode demonstrasi terhadap hasil belajar kognitif siswa. Dan ada perbedaan pengaruh antara penggunaan pendekatan induktif melalui metode eksperimen disertai pemberian tugas dan metode demonstrasi disertai pemberian tugas terhadap kemampuan kognitif siswa. Penggunaan metode eksperimen disertai pemberian tugas memberikan kemampuan kognitif lebih baik daripada melalui metode demonstrasi disertai pemberian tugas.
\end{abstract}

Kata Kunci: Pendekatan Induktif, Metode Eksperimen dan Demonstrasi, Hasil Belajar Kognitif

Abstract: This study aims to determine whether there is a difference in the effect of learning physics with an inductive approach through experimental and demonstration methods on cognitive learning outcomes of class $X$ MA Safinatunnaja NW Repok Oak. This study uses an experimental method with a factorial design. The population in this study were all students of class X Semester II SM Safinatunnaja NW Repok Oak for the 2018/2019 academic year. Data collection techniques used are observation techniques, documentation techniques and test techniques. The implication of the research results is that learning Physics with an inductive approach using the experimental method has a better effect by getting an average score on cognitive outcomes of 90.21 out of 28 students, while using the demonstration method gets an average score of 80.87 out of 31 students. In addition, the initial ability of students in the high category will provide better cognitive abilities than the initial abilities of students in the medium and low categories. Based on the results of the research analysis, it can be concluded that there is an effect of using an inductive approach through the experimental method on students' cognitive learning outcomes. Then there is the effect of using an inductive approach through the demonstration method on students' cognitive learning outcomes. And there is a difference in the effect between the use of the inductive approach through the experimental method with assignments and demonstration methods with assignments on students' cognitive abilities. The use of the experimental method accompanied by assignments provides better cognitive abilities than through the demonstration method accompanied by assignments.

Keywords: Inductive Approach, Experiment and Demonstration Method, Cognitive Learning Outcomes 


\section{Pendahuluan}

Pendidikan merupakan bagian yang tidak dapat dipisahkan dari hidup dan kehidupan manusia. Bagaimanapun sederhana komunitas manusia memerlukan pendidikan. Maka dalam pengertian umum, kehidupan dan komunitas tersebut akan di tentukan oleh oktifitas pendidikan di dalamnya. Sebab pendidikan secara alami sudah merupakan kebutuhan hidup manusia.

Menurut Jalaluddin dalam buku ramayulis bagi manusia yang hidup di lingkungan masyarakat yang masih sederhana, pendidikan dilakukan lansung oleh para orang tua. Pendidikan akan dinilai rampung bila anak mereka sudah mengijak usia dewasa, manpu mandiri setelah menguasai sejumlah keterampilan praktis sesuai dengan tuntutan dan kebutuhan hidup di masyarat lingkungannya.

Tujuan dan misi pendidikan yang di laksanakan pada prinsipnya sama yaitu memberi bimbingan agar dapat hidup mandiri. Dalam perkembangannya pengertian pendidikan selalu mengalami perubahan menuju kesempurnaan dan akhirnya pendidikan berarti usaha sadar dan terencana untuk mewujudkan suasana belajar dan proses pembelajran agar peserta didik secara aktif mengembangkan potensi dirinya untuk memiliki kekuatan spritual, pengendalian diri, kepribadian, kecerdasan serta keterampilan yang diperlukan bagi dirinya, msyarakat dan Negara

Untuk mencapai tujuan pembelajaran yang diharapkan dalam proses pembelajaran Tenaga pendidik hendaknya menggunakan pendekataan pembelajaran yang dapat melibatkan aktivitas peserta didik dan yang dapat membantu peserta didik memahami konsep-konsep fisika yang sulit.

Salah satu pelajaran yang sangat penting dan berpengaruh besar dalam dunia pendidikan dan teknologi adalah Fisika. Tetapi kenyataan pelajaran fisika justru menjadi momok bagi kebanyakan peserta didik dan akar segala kesulitan. Sebagian besar peserta didik cenderung tidak tertarik pada pelajaran fisika dan menganggap pelajaran paling rumit, menegangkan dan sukar untuk dipelajari. Padahal ketidak senangan terhadap suatu pelajaran misalnya pelajaran fisika akan berpengaruh terhadap keberhasilan pembelajaran. Pendidik harus pandai menciptakan suasana menyenangkan dalam proses pembelajaran agar mindset peserta didik dapat berubah mengenai pelajaran fisika. Salah satunya dengan memilih strategi pembelajaran yang sesuai dengan karakteristik peserta didik.

Berdasarkan hasil observasi yang peneliti lakukan di Madrasah Aliyah Safinatunnaja NW Repok Oak kelas X yang dimana seorang guru khususnya pada mata pelajaran IPA melakukan suatu proses pengajaran terhadap siswa hanya dengan menggunakan metode ceramah, selain itu siswa hanya disuruh menulis apa yang sudah dipaparkan dipapan tulis. Peneliti mendapatkan sebuah ungkapan dari hasil wawancara terhadap guru Fisika di madrasah tersebut adalah salah satu masalah yang dihadapi oleh guru dalam proses belajar mengajar adalah lemahnya proses pembelajaran karena keterbatasan dalam menerapkan model-model ataupun metodemetode pembelajaran. Dan beberapa siswa menyatakan bahwa apa yang dipelajari dari mata pelajaran tersebut tidak dapat dimengerti bahkan sulit untuk memahami apa yang sedang dipelajari. Tidak hanya dengan monotonnya metode yang digunakan akan tetapi kurangnya motivasi terhadap minat belajar siswa. Sehingga hasil belajar yang dicapai siswa dalam mata pelajaran fisika masih belum mencapai kriteria ketuntasan minimun (KKM). Hal ini terlihat dari hasil rekafitulasi nilai ujian akhir pada semester sebelumnya dengan tingkat KKM 70 mendapatkan nilai rata-rata adalah 65 . Berdasarkan hal tersebut peneliti ingin membuktikan pengaruh penggunaan metode eksperimen dan demonstrasi serta ingin membandingkan pengaruh metode eksperimen dengan metode demonstrasi terhadap hasil belajar kognitif siswa.

Fisika terdiri atas konsep-konsep. Konsep pada dasarnya mengategorisasikan sesuatu kedalam penyajian non-verbal, sehingga konsep cenderung bersifat abstrak sehingga kemampuan gambaran mental diperlukan. Konsep merupakan bayangan mental dan proses. Suatu konsep memiliki suatu organisasi kognitif yang berguna untuk memecahkan masalah baru yang ditemukan. 
Sehingga dapat disimpulkan bahwa pemahaman konsep fisika adalah kemampuan siswa untuk mengetahui mendefinisikan dan membahasakan sendiri konsep fisika yang telah dipelajarinya tanpa mengurangi maknanya. Untuk memudahkan siswa dalam memahami konsep maka seharusnya pembelajaran yang dihadapkan kepada siswa adalah pembelajaran yang menghadapkan siswa pada masalahmasalah di kehidupan sehari-hari siswa, sehingga pembelajaran siswa lebih bermakna.

Sehingga pendekatan dan metode mengajar yang digunakan oleh pengajar berpengaruh terhadap keberhasilan proses belajar mengajar, oleh karena itu seorang guru atau pengajar harus mampu memilih pendekatan dan metode mengajar yang tepat sehingga proses belajar mengajar dapat berlangsung baik, efektif dan efisien. Memilih pendekatan dan metode mengajar harus disesuaikan dengan tujuan pengajaran, kemampuan guru, kemampuan siswa dan fasilitas yang tersedia.

Pemilihan dan penggunaan berbagai macam model atau pendekatan menjadi penting karena baik aspek kognitif dan afektif dalan tujuan pembelajaran memiliki karakteristik yang berbeda-beda akan tetapi saling terkait satu sama lain.

Penggunaan berbagai macam model atau pendekatan dalam mengajar menjadi keharusan bagi seorang guru ketika melakukan proses pembelajaran di kelas. Keharusan tersebut tertuang dalam Permendiknas no. 16 tahun 2007 mengenai standar kualifikasi akademik dan kompetensi guru, kompetensi yang terkait dengan pengunaan berbagai macam model atau pendekatan dalam mengajar adalah kompetensi pedagogic.

Suriasumantri Amri dalam jurnal Ani Aisyah menyatakan bahwa "Induktif merupakan cara berpikir di mana suatu kesimpulan yang bersifat umum dari berbagai kasus yang bersifat individual". Pembelajaran dengan pendekatan induktif dimulai dengan melakukan pengamatan terhadap hal-hal khusus dan menginterpretasikannya, menganalisis kasus, atau memberi masalah kontekstual, siswa dibimbing memahami konsep, aturan-aturan, dan prosedur-prosedur berdasar pengamatan siswa sendiri. Hal ini sejalan dengan Hudoyo dalam jurnal Ani Aisyah yang mengatakan bahwa pendekatan induktif berperan dari hal-hal yang bersifat konkret ke yang bersifat abstrak, dari contoh-contoh khusus ke rumus umum.

Adapun menurut Sartika dalam jurnal Andri Desy Astuti "metode eksperimen adalah suatu cara penyampaian pengajaran dengan melakukan kegiatan percobaan untuk menemukan sendiri apa yang dipelajari baik secara individu maupun kelompok, sehingga siswa mampu mengecek kebenaran suatu hipotesis atau membuktikan sendiri apa yang dipelajari.

Selain dengan menggunakan metode pembelajaran eksperimen dapat pula menggunakan metode pembelajaran demonstrasi. Metode pembelajaran demonstrasi. Menurut Suryani, N. dan Agung, L. dalam jurnal Andri Desy Astuti adalah cara penyajian bahan pelajaran dengan memperagakan atau mempertunjukkan kepada siswa suatu proses, situasi atau benda tertentu yang sedang dipelajari, baik sebenarnya atau tiruan yang disertai dengan penjelasan.

Berdasarkan uraian di atas penulis melakukan penelitian yang berkaitan dengan metode pembelajaran untuk mendukung kemampuan kognitif siswa, maka dalam penelitian ini dipilih judul: "Pengaruh Pembelajaran Fisika Dengan Pendekatan Induktif Melalui Metode Eksperimen dan Demonstrasi Terhadap Hasil Belajar Kognitif Siswa Kelas X MA Safinatunnaja NW Repok Oak".

\section{Metode Penelitian}

\section{A. Desain Penelitian}

Desain penelitian yang digunakan adalah Factorial Desain, yang dimana menurut Sugiyono (2012:76) desain faktorial merupakan modifikasi dari design true experimental, yaitu dengan memperhatikan kemungkinan adanya variabel moderator yang mempengaruhi perlakuan (variabel independen) terhadap hasil (dpenden).

B. Instrumen/Alat dan Bahan Penelitian

Pada penelitian ini digunakan instrumen penelitian yang berupa instrumen saat penelitian dan instrumen pengambilan data. 
1. Instrumen saat penelitian, meliputi Rencana Pembelajaran (RP), Lembar kerja Siswa (LKS), Lembar soal tugas.

2. Instrumen pengambilan data, yaitu soal tes kemampuan kognitif berbentuk pilihan ganda, tes dibuat sama antara kelompok eksperimen dan kelompok kontrol. Untuk menjaga kualitas instrumen penelitian dilakukan konsultasi.

Sebelum diteskan, instrumen tes harus diujicobakan terlebih dahulu. Adapun uji yang dilakukan terhadap instrumen tersebut meliputi validitas item tes, reliabilitas, daya pembeda, dan taraf kesukaran.

C. Teknik Pengumpulan Data/Prosedur Penelitian

Pada penelitian ini teknik pengumpulan data yang digunakan sebagai berikut:

\section{Teknik Observasi}

Observasi adalah kegiatan pengumpulan data dengan melakukan penelitian langsung terhadap kondisi lingkungan objek penelitian yang mendukung kegiatan penellitian, sehingga didapatkan gambaran secara jelas tentang kondisi objek penelitian tersebut.

\section{Teknik Dokumentasi}

Teknik dokumentasi dalam penelitian ini digunakan untuk memperoleh data kemampuan awal kedua kelompok yaitu kelompok kontrol dan kelompok eksperimen, sebelum mendapat perlakuan. Data ini dipakai dari nilai ulangan sub pokok bahasan suhu dan mengambil data yang telah ada.

3. Teknik Tes

Teknik ini digunakan untuk memperoleh data kemampuan kognitif siswa setelah diberikan perlakuan. Pengamat menyiapkan alat penilaian kemampuan kognitif siswa setelah diberikan perlakuan.
Tes ini digunakan untuk mengukur kemampuan kognitif siswa pada materi pokok bahasan kalor.

D. Jenis dan Pendekatan Penelitian Jenis yang digunakan dalam penelitian ini adalah eksperimen dengan menggunakan penelitian kuantitatif. Pada metode eksperimen sebagai bagian dari kuantitatif mempunyai ciri khas tersendiri, terutama dengan adanya kelompok kontrol.

E. Teknik sampel yang digunakan dalam penelitian ini adalah teknik cluster random sampling. Pengambilan sampel dengan cara cluster random sampling adalah melakukan randomisasi terhadap kelompok bukan terhadap subjek secara individual.

Dari populasi di atas dipakai sampel yang terdiri dari 2 kelas yaitu kelas X-A sebagai kelas eksperimen dan kelas X-B sebagai kelas kontrol.

F. Uji Validitas

Validitas suatu instrumen menunjukkan tingkat ketepatan suatu instrumen untuk mengukur apa yang harus diukur. Jadi validitas suatu instrumen berhubungan dengan tingkat akurasi dari suatu alat ukur mengukur apa yang akan diukur (Alfira Mulya Astuti 2016).

Menurut Sugiyono (2012 : 121) hasil penelitian yang valid bila terdapat kesamaan antara data yang terkumpul dengan data yang sesungguhnya terjadi pada obyek yang diteliti. Teknik untuk mengukur validitas pada penelitian digunakan korelasi point biseral.

Validitas suatu instrumen dikelompokkan menjadi:

1. Validitas isi (content Validity), berkenaan dengan isi dan format dari instrumen. Apakah butir-butir pertanyaan telah mewakili aspekaspek yang akan diukur dan apakah pemilihan format instrumen cocok untuk mengukur aspek tersebut. 
3. Validitas konstruk (construct validity), berkenaan dengan kesesuaian aspek-aspek yang akan diukur dengan pendapat para ahli.

4. Validitas kriteria (criterion validity)/ empiris/ eksternal, berkenaan dengan tingkat ketepatan instrumen mengukur segi yang akan diukur dibandingkan dengan hasil pengukuran dengan instrumen lain yang menjadi kriteria. Instrumen diuji dengan cara membandingkan kriteria yang ada pada instrumen dengan fakta empiris yang terjadi dilapangan. Validitas kriteria ditentukan dengan engkorelasikan skor tiap butir atau item pertanyaan pada instrumen dari masing-masing responden dengan skor total dari masing-asing responden.

Jika nilai koefisien product momen pearson (r) yang diperoleh adalah positif, kemungkinan butir yang diuji tersebut adalah valid. Walaupun positif perlu pula nilai product momen pearson $(r)$ tersebut diuji signifikan atau tidaknya. Jika korelasi signifikan maka item instrumen adalah valid. Untuk menguji signifikasi nilai product momen pearson berdasaarkan hasil analisis ( $\mathrm{r}_{\text {hitung }}$ ) itu dibandingkan dengan nilai koefisien product momen pearson tabel $\left(\mathrm{r}_{\text {tabel }}\right)$ pada taraf signifikasi $\alpha$ (biasanya dipilih 0,05 ) dan $\mathrm{n}=$ banyak data yang sesuai. Berikut ini kriteria keputusan bahwa instrumen butir ke-i valid atau tidak.

a. Instrumen valid, jika $r_{\text {hitung }} \geq r_{\text {tabel }}$

b. Instrumen tidak vali, jika $r_{\text {hitung }}<r_{\text {tabel }}$

G. Teknik Analisis Data

1. Statistik Deskriptif

Teknik analisis data dalam penelitian kuantitatif menggunakan statistik. Terdapat beberapa dua macam statistik yang digunakan untuk analisis data dalam penelitian, yaitu statistik deskriptif, dan statistik (Sugiyono 2012 :147). Dalam penelitian ini menggunakan penelitian deskriptif.

$\begin{array}{rrr}\text { Statistik } & \text { deskriptif } & \text { adalah } \\ \text { statistik yang } & \text { digunakan } & \text { untuk }\end{array}$

menganalisis data dengan cara mendeskripsikan atau menggambarkan data yang telah terkumpul sebagaimana adanya tanpa bermaksud membuat kesimpulan yang berlaku untuk umum atau generalisasi (Sugiyono 2012: 147).

2. Uji Prasyarat

a. Uji Normalitas

Uji normalitas digunakan untuk mengetahui apakah populasi data berdistribusi normal atau tidak. Salah satu pengujian normalitas dengan menggunakan teknik Kolmogrov Smirnov. Uji kolmogrov smirnov adalah pengujian normalitas yang banyak dipakai, terutama setelah adanya banyak program statistik yang beredar. Kelebihan dari uji ini adalah sederhana dan tidak menimbulkan perbedaan persepsi diantara satu pengamat dengan pengamat yang lain, yang sering terjadi pada uji normalitas dengan menggunakan grafik. Kriteria pengujian seperti pada uji beda biasa, jika signifikasi dibawah 0,05 berarti terdapat perbedaan yang signifikan, dan jika signifikasi diatas 0,05 maka tidak terjadi perbedaan yang signifikan.

b. Uji Homogenitas

Dalam menguji kesamaan dua rata-rata berulangkali diperlukan informasi tentang kesamaan variansi dari dua populasi agar proses pengujian dapat dilakukan. Misalkan dimiliki dua populasi normal dengan variansi masing-masing $\sigma_{1}^{2}$ dan $\sigma_{2}^{2}$.

Berdasarkan sampel acak yang masing-masing secara bebas diambil dari populasi tersebut, dapat diuji pasangan hipotesis ini dengan uji F. Sampel dari populasi pertama berukuran $\mathrm{n}_{\mathrm{i}}$ dengan variansi $s_{1}^{2}$ dan sampel dari populasi kedua berukuran $\mathrm{n}_{2}$ 
dengan variansi $s_{2}^{2}$, maka statistik $F$ dapat dihitung dengan rumus:

$\boldsymbol{F}_{\text {hitung }}=\frac{\text { varians terbesar }}{\text { varians terkecil }}$

Yang memiliki distribusi snedecor $F$ dengan derajat kebebasan $\left(\mathrm{n}_{1}-1, \mathrm{n}_{2}-1\right)$ dengan hipotesis nol besar. Derajat kebebasan $\mathrm{n}_{2}-1$ disebut kebebasan penyebut.

Kriteria pengambilan keputusan.

Jika $\mathbf{F}_{\text {hitung }}<\mathbf{F}_{\text {tebel, }}$ maka data homogen

Jika $\mathbf{F}_{\text {hitung }} \geq \mathbf{F}_{\text {tabel}}$, maka data tidak homogen.

c. Uji Hipotesis

Hipotesis adalah pernyataan yang diterima sementara dan masih perlu diuji kebenarannya. Adapun teknik uji yang digunakan adalah uji-t dengan rumus:

$t=\frac{\overline{\bar{x}}_{1}-\bar{x}_{2}}{\sqrt[s]{\frac{1}{n_{1}+\frac{1}{n_{2}}}}}$

Dengan $\mathrm{s}^{2}$ adalaha variansi gabungan yang dihitung dengan rumus:

$s^{2}=\frac{\left(n_{1}-1\right) s_{1}^{2}+\left(n_{2}-1\right) s_{2}^{2}}{n_{1}+n_{2}-2}$

Statistik $\mathrm{t}$ diatas berdistribusi student atau berdistribusi $t$ dengan derajat kebebasan $\mathrm{dk}=\mathrm{n}_{1}+\mathrm{n}_{2}-$ 2.

\section{Hasil Penelitian dan Pembahasan}

Hasil dari penelitian ini terdapat dua variabel yaitu variabel bebas dan variabel terikat. Variabel bebasnya adalah pembelajaran fisika dengan pendekatan induktif melalui metode eksperimen dan demonstrasi dan variable terikatnya adalah kemampuan kognitif siswa.

Pada penelitian ini jumlah siswa yang dilibatkan sebanyak 59 siswa dari kelas X-A berjumlah 28 siswa dan X-B berjumlah 31 siswa yang mengikuti pengajaran di MA Safinatunnaja NW Repok Oak tahun pelajaran 2018/2019. Data yang diperoleh dalam penelitian ini yaitu data kemampuan awal siswa dan nilai kemampuan kognitif pada sub pokok bahasan kalor. Data yang terkumpul dikelompokkan menjadi dua yaitu kelompok eksperimen (X-A) dan kelompok kontrol (XB).

a. Data hasil kemampuan awal siswa Nilai kemampuan awal yang digunakan adalah nilai hasil pretest.

\begin{tabular}{llll}
\multicolumn{3}{c}{ Table 1. Deskrpsi Data Kemampuan Awal Siswa (pretest) } \\
\hline Kelompok & Jumlah & Nilai & Nilai \\
& Siswa & Tertinggi & Terendah \\
\hline Eksperimen & 28 & 95 & 45 \\
Kontrol & 31 & 95 & 45 \\
\hline
\end{tabular}

\begin{tabular}{llll}
\hline Kelompok & $\begin{array}{l}\text { Rata- } \\
\text { Rata }\end{array}$ & $\begin{array}{l}\text { Standar } \\
\text { Deviasi }\end{array}$ & Variansi \\
\hline Eksperimen & 77.5714 & 8.1691 & 66.7354 \\
Kontrol & 68.4032 & 2.0202 & 4.0815 \\
\hline
\end{tabular}

Dari perhitungan diatas maka didapatkan distribusi frekuensi kategori kemampuan awal pada kelas eksperimen yang disajikan pada tabel 2.

Tabel 2. Distribusi Frekuensi KategoriKemampuan Awal (Pretest) Kelas Eksperimen

\begin{tabular}{ccc}
\hline \multirow{2}{*}{ Kategori } & \multicolumn{2}{c}{ Frekuensi } \\
\cline { 2 - 3 } & F mutlak & F relatif \\
\hline Tinggi & 19 & $67.85 \%$ \\
Sedang & 3 & $10.71 \%$ \\
Rendah & 6 & $21.42 \%$ \\
\hline
\end{tabular}

Tabel 3. Distribusi Frekuensi Kategori Kemampuan Awal (Pretest) Kelas Kontrol

\begin{tabular}{ccc} 
& \multicolumn{2}{c}{ (Pretest) Kelas Kontrol } \\
\cline { 2 - 3 } Kategori & \multicolumn{2}{c}{ Frekuensi } \\
\cline { 2 - 3 } & F mutlak & F relatif \\
\hline Tinggi & 7 & $22.58 \%$ \\
Sedang & 20 & $64.51 \%$ \\
Rendah & 4 & $12.90 \%$ \\
\hline
\end{tabular}

Distribusi frekuensi kemampuan awal pada kelas eksperimen dissajikan pada tabel 4, sedangkan distribusi frekuensi kemampuan awal pada kelas kontrol disajikan pada tabel 5 . 
Tabel 4. Distribusi Frekuensi Kemampuan Awal Kelas

\begin{tabular}{cccr} 
& \multicolumn{4}{c}{ Eksperimen } \\
\hline Interval & Titik & \multicolumn{2}{c}{ Frekuensi } \\
\cline { 3 - 4 } Kelas & Tengah & Tutlak & elatif \\
\hline $45-53$ & 49 & 3 & $10.71 \%$ \\
$54-62$ & 58 & 2 & $7.14 \%$ \\
$63-71$ & 67 & 1 & $3.57 \%$ \\
$72-80$ & 76 & 9 & $32.14 \%$ \\
$81-88$ & 84.5 & 6 & $21.42 \%$ \\
$89-97$ & 93 & 7 & $25 \%$ \\
\hline
\end{tabular}

Tabel 5. Distribusi Frekuensi Kemampuan Awal Kelas Kontrol

\begin{tabular}{rrrr}
\hline Interval & Titik & \multicolumn{2}{c}{ Frekuensi } \\
\cline { 3 - 4 } Kelas & Tengah & Mutlak & Relatif \\
\hline $45-53$ & 49 & 2 & $6.45 \%$ \\
$54-62$ & 58 & 2 & $6.45 \%$ \\
$63-71$ & 67 & 19 & $61.29 \%$ \\
$72-80$ & 76 & 6 & $19.35 \%$ \\
$81-88$ & 84.5 & 1 & $3.22 \%$ \\
$89-97$ & 93 & 1 & $3.22 \%$ \\
\hline
\end{tabular}

Untuk memperjelas distribusi frekuensi kemampuan awal siswa tersebut disajikan histogram dari masing-masing distribusi pada gambar 1 dan 2.

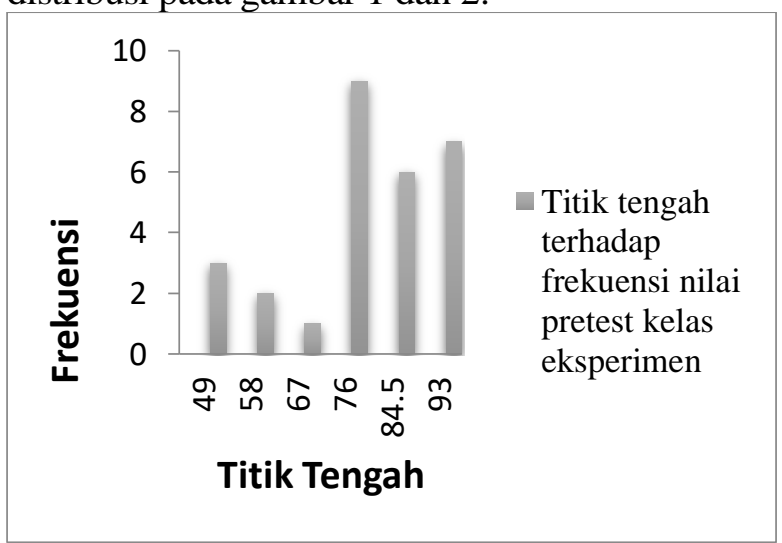

Gambar 1. Histogram Kemampuan Awal Kelas Eksperimen

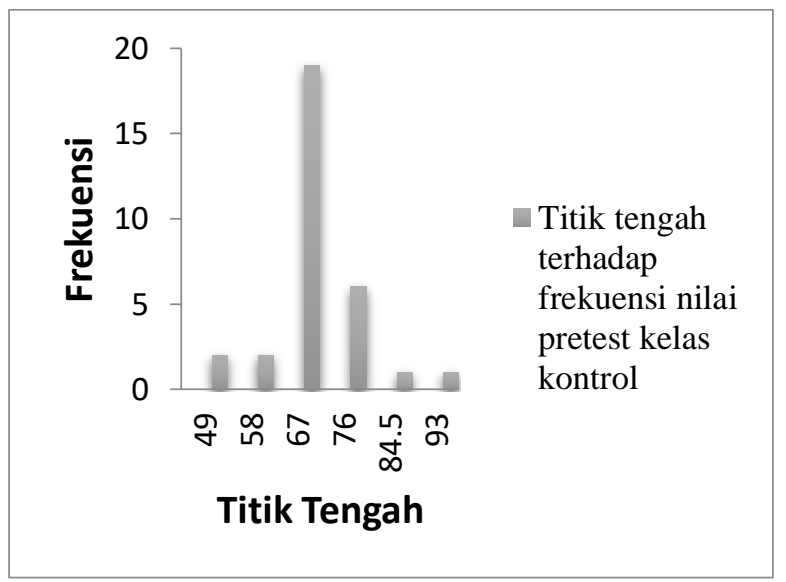

Gambar 2. Histogram Kemampuan Awal Kelas Kontrol b. Data nilai kemampuan kognitif siswa

\begin{tabular}{|c|c|c|c|}
\hline Kelompok & $\begin{array}{c}\text { Jumlah } \\
\text { Siswa }\end{array}$ & $\begin{array}{c}\text { Nilai } \\
\text { Tertinggi }\end{array}$ & $\begin{array}{c}\text { Nilai } \\
\text { Terendah }\end{array}$ \\
\hline Eksperimen & 28 & 95 & 70 \\
\hline Kontrol & 31 & 95 & 60 \\
\hline Kelompok & $\begin{array}{l}\text { Rata- } \\
\text { Rata }\end{array}$ & $\begin{array}{l}\text { Standar } \\
\text { Deviasi }\end{array}$ & Variansi \\
\hline Eksperimen & 90.21 & 7.479 & 55.95 \\
\hline Kontrol & 80.87 & 6.909 & 4.774 \\
\hline
\end{tabular}

Distribusi frekuensi nilai kemampuan kognitif siswa kelas eksperimen dan kelas kontrol disajikan pada tabel 7 dan tabel 8 .

Tabel 7. Distribusi Frekuensi Kemampuan KognitifKelas

\begin{tabular}{cccc} 
& \multicolumn{3}{c}{ Eksperimen } \\
\hline Interval & Titik & \multicolumn{2}{c}{ Frekuensi } \\
\cline { 3 - 4 } Kelas & Tengah & Mutlak & Relatif \\
\hline $70-74$ & 72 & 2 & $7.14 \%$ \\
$75-79$ & 77 & 1 & $3.57 \%$ \\
$80-84$ & 82 & 3 & $10.71 \%$ \\
$85-89$ & 87 & 2 & $7.14 \%$ \\
$90-94$ & 92 & 11 & $39.28 \%$ \\
95-99 & 97 & 9 & $32.14 \%$ \\
\hline
\end{tabular}

Tabel 8. Distribusi Frekuensi Kemampuan KognitifKelas Kontrol

\begin{tabular}{cccc}
\hline Interval & Titik & \multicolumn{2}{c}{ Frekuensi } \\
\cline { 3 - 4 } Kelas & Tengah & Mutlak & Relatif \\
\hline $60-65$ & 62.5 & 2 & $6.25 \%$ \\
$66-71$ & 68.5 & 3 & $9.67 \%$ \\
$72-77$ & 74.5 & 3 & $9.67 \%$ \\
$78-83$ & 80.5 & 13 & $41.9 \%$ \\
$84-89$ & 86.5 & 3 & $9.67 \%$ \\
$90-95$ & 92.5 & 7 & $22.5 \%$ \\
\hline
\end{tabular}

Untuk memperjelas distribusi frekuensi nilai kemampuan kognitif tersebut, disajikan histogram pada gambar 3 dan 4 . 


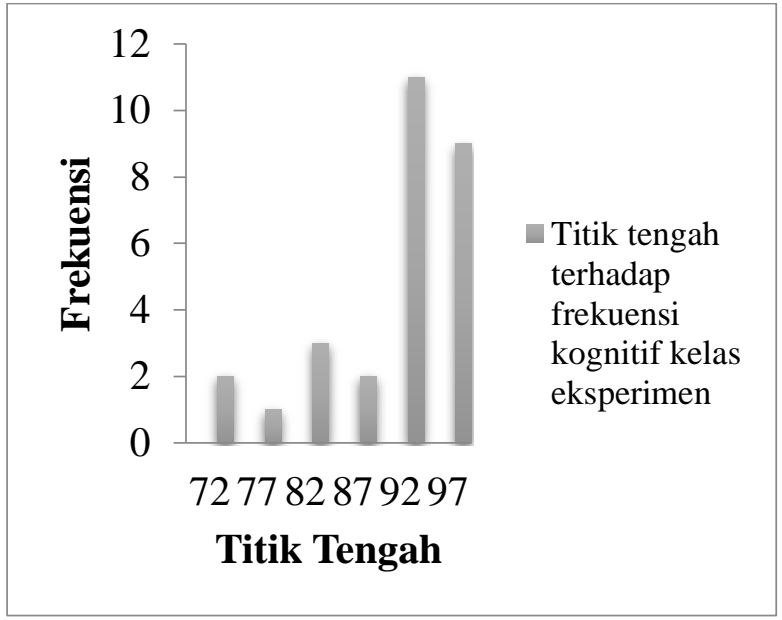

Gambar 3. Histogram Nilai Kognitif Kelas Eksperimen

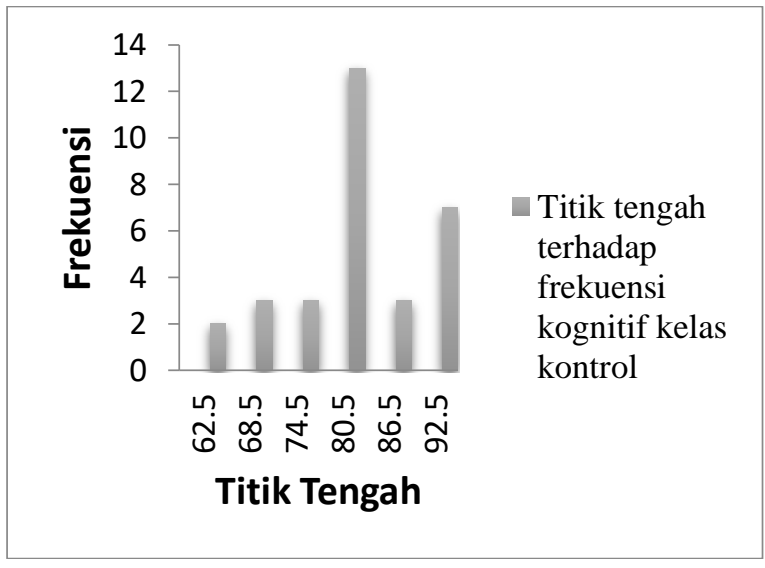

Gambar 4.4. Histogram Nilai Kognitif Kelas Kontrol

Berdasarkan data diatas diperoleh perbedaan pengaruh antara penggunaan pendekatan induktif melalui metode eksperimen dan metode demonstrasi terhadap kemampuan kognitif siswa kelas $\mathrm{X}$ MA Safinatunnaja NW Repok Oak. Tahun Ajaran 2018/2019.Dari tabel 4.6 terlihat bahwa kemampuan kognitif siswa yang diberi perlakuan pembelajaran dengan menggunakan pendekatan induktif melalui metode eksperimen mempunyai rerata yang lebih besar yaitu 90.21dari 28 siswa yang dimana nilai tertinggi dari hasil kognitif siswa pada kelas eksperimen adalan 95 dan nilai terendah adalah 70 dengan standar deviasi 7.479 dan nilai variansi adalah 55.95. Dibanding dengan siswa yang diberi perlakuan dengan metode demonstrasimemiliki nilai rata-rata 80.87dari 31 siswa yang dimana nilai tertinggi adalah 95 , sementara nilai terendah adalah 60 dengan nilai standar deviasi 2.184 dan nilai variansi adalah 4.774 .

\section{Kesimpulan dan Rekomendasi}

\section{A. Kesimpulan}

Berdasarkan hasil analisis penelitian dapat disimpulkan bahwa ada pengaruh penggunaan pendekatan induktif melalui metode eksperimen terhadap hasil belajar kognitif siswa. Ada pengaruh penggunaan pendekatan induktif melalui metode demonstrasi terhadap hasil belajar kognitif siswa. Ada perbedaan pengaruh antara penggunaan pendekatan induktif melalui metode eksperimen disertai pemberian tugas dan metode demonstrasi disertai pemberian tugas terhadap kemampuan kognitif siswa . Penggunaan metode eksperimen disertai pemberian tugas memberikan kemampuan kognitif lebih baik daripada melalui metode demonstrasi disertai pemberian tugas.

Kekurangan dalam penelitian ini adalah kurangnya alat atau fasilitas dalam melaksanakan metode eksperimen sehingga dalam pelaksanaannya hanya menggunakan tiga kelompok yang seharusnya menggunakan enam kelompok, maka dalam proses pembelajaran siswa sangat kesulitan dalam mengambil data pada eksperimennya.

\section{B. Rekomendasi}

Pada penelitian ini penulis menyadari bahwa karya ini jauh dari kesempurnaan baik dalam pelaksanaan, panduan penyusunannya. Demi terselenggara sistem pengajaran yang dapat mencapai tujuan yang telah ditetapkan dengan baik, maka dapat diajukan saran sebagai berikut:

1. Agar pendekatan induktif dapat berlangsung dengan baik, maka pada pelaksanaanya diusahakan:

a. Guru atau penelitiselanjutnya harus mampu menguasai dan memimpin kelas dengan baik sehingga jalannya eksperimen dapat berlangsung dengan 
tertib.

b. Guru atau peneliti selanjutnya harus sering membuat siswa aktif di dalam kegiatan belajar mengajar.

c. Guru atau peneliti selanjutnya harus sering memberikan latihan soal dan tugas setiap akhir pembelajaran agar siswa lebih mendalami materi yang telah disampaikan.

2. Untuk dapat melaksanakan pengajaran pendekatan induktif dengan baik hendaklah guru memilih pendekatan dan metode yang sesuai dengan materi pelajaran dan tingkat intelegensi siswa.

\section{Daftar Pustaka}

Ahmad Gunawan, Hairunnisyah Harjono, Sahidu, pengembangan model laboratorium virtual berorientasi pada kemampuan pemecahan masalah bagi calon guru fisika, volume 5, nomor 2 , tahun 2015, hlm. 41.

Aisyah Ani, Pendekatan Induktif Untuk Meningkatkan Kemampuan Generalisasi Dan Self Confident Siswa SMK. Volume 2, Nomor 1, Maret Tahun 2016, hlm. 2-3.

Amasse S, Yusuf Hidayat Muh, Jusriana. A. Pendekatan Pembelajaran Deduktif Dan Pembelajaran Induktif Untuk Meningkatkan Keterampilan Bertanya Pokok Bahasan Pemuaian Kelas Vii Smp Negeri 21 Makassar, Volume 4, Nomor 2, Tahun 2016, hlm. 1.

Desy Astuti Andri , Handhika Jeffry, Kartikawati Sulistyaning., Perbedaan Pengaruh Penggunaan Methode Pembelajaran Eksperimens Dan Demonstrasi Berbentukan PCB. Sederhana Di Tinjau Dari Kreativitas Siswa Terhadap Hasil Belajar Siswa. Volume 2, Nomor 2, September Tahun 2017, hlm. 8

Hanna Daryl, Sutarto, Harijanto Alex, Model Pembelajaran Tema Konsep Disertai Media Gambar Pada Pembelajaran
Fisika Di Sma, Volume 5, Nomor 1, Juni Tahun 2016, hlm 23.

Hasriani, Peranan Model Pembelajaran Berfikir Induktif Terhadap Hasil Belajar Fisika Peserta Didik Kelas VII A SMP Aksara Bajeng, Volume 2 Nomor 3 Tahun 2012, hlm. 218-219.

Hikmawati, Strategi Pembelajaran Fisika, Mataram: FKIP Pres UNRAM, 2014.

Iskandar Akbar, Muhammad Rizal, Analisis Kualitas Soal Di Perguruan Tinggi Berbasis Aplikasi TAP, Volume 21 Nomor 2, Tahun 2017, hlm 14-15.

Kurniawati Endang, Rahman Aththibby Arif, Peningkatan Aktivitas Dan Hasil Belajar Menggunakan Metode Eksperimen Pada Siswa Kelas VII SMP Negeri 1 Purbolinggo Tahun Pelajaran 2013/2014, hlm. 52.

Lutvaidah Ukti, Pengaruh Metode Dan Pendekatan Pembelajaran Terhadap Penguasaan Konsep Matematika, 2015, hlm. 282.

Mahmud. Metode Penelitian Pendidikan. Bandung: Pustaka Setia.2011.

Mulya Astuti Alfira. Statistika Penelitian. Insan Madani Publishing Mataram. 2016.

Muslich, Masnur. KTSP Pembelajaran Berbasis Kompetensi dan Kontekstual. Jakarta: PT Bumi Aksara. 2016

Nasution, S. Kurikulum dan Pengajaran. Bandung: Bina Aksara. 2016.

Purwanto, Evaluasi Hasil Belajar, Yogyakarta: Pustaka Pelajar, 2016.

Ramayulis, Ilmu Pendidikan Islam, Tahun 2013.

Rusmawati, Meningkatkan Hasil Belajar Fisika Peserta Didik Melalui Strategi Pembelajaran Discovery Terbimbing Kelas X MIA2 SMA Negeri I Barru, Volume 5 Nomor 1 Tahun 2016, hlm. 2.

Sanjaya, Wina. Strategi Pembelajaran Berorientasi Standar Proses Pendidikan. Jakarta: Kencana. 2011.

Sanjaya, Wina. Pembelajaran dalam Implementasi Kurikulum Berbasis Kompetensi. Jakarta: Kencana, Prenada Media Group. 2014.

Saregar Antomi, dkk, Pembelajaran Fisika Kontekstual Melalui Metode Eksperimen Dan Demonstrasi Diskusi Menggunakan Multimedia Interaktif 
Ditinjau Dari Sikap Ilmiah Dan Kemampuan Verbal Siswa, Volume 2 Nomor 2 Tahun 2013, hlm 112.

Sudjana Nana. Dasar-dasar Proses Belajar Mengajar. Bandung: Sinar Baru Algesindo. 2016.

Sugiyono, Metode Penelitian Kuantitatif Kualitatif Dan R \& D, Gegerkalang Hilir: Bandung,2012.
Supu Idawati, dkk, Pengaruh suhu terhadap perpindahan panas pada material yang berbeda, Volume 7 No 1 Apri Tahun 2016, hlm 66-68.

Wiratma Jaya Gede, Patasik Boas,Eka, Penerapan Pendekatan Saintifik Melalui Metode Eksperimen Pada Pembelajaran Fisika Siswa Kelas X Mia 3 Sma Negeri 1 Tenggarong (Materi Suhu Dan Kalor), Maret Tahun 2016, hlm. 24. 